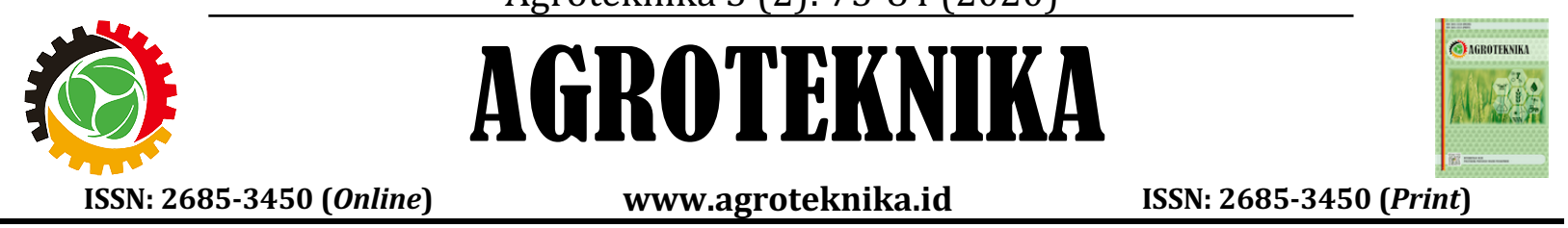

\title{
Analisis Pertumbuhan Padi Lokal Aksesi PH 1 Menggunakan Penambahan Pupuk Silika Padat pada Kondisi Salin
}

\section{The Growth Analysis of Local Rice Accession PH 1 Using Addition Solid Silica Fertilizer under Saline Conditions}

\author{
Nasrudin*, Arrin Rosmala \\ Program Studi Agroteknologi, Fakultas Pertanian, Universitas Perjuangan Tasikmalaya, \\ Indonesia \\ *Penulis Korespondesi \\ Email: nasrudin@unper.ac.id
}

\begin{abstract}
Abstrak. Analisis pertumbuhan padi penting diketahui untuk menggambarkan kondisi tumbuh kembang tanaman sehingga dapat berproduksi secara optimal utamanya pada kondisi suboptimal. Tujuan penelitian yaitu mengetahui proses fisiologi dan produksi biomasa padi lokal aksesi PH 1 pada kondisi salin dengan penambahan pupuk silika padat. Penelitian menggunakan Rancangan Acak Lengkap dengan dua faktor. Faktor pertama tingkat cekaman salinitas dengan

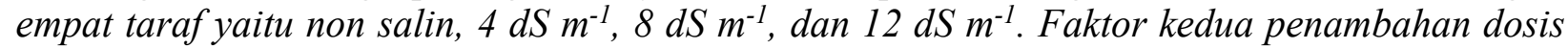
silika padat per $\mathrm{kg}$ tanah dengan tiga taraf yaitu $300 \mathrm{mg}$, $450 \mathrm{mg}$, dan $600 \mathrm{mg}$. Hasil penelitian menunjukkan bahwa terdapat interaksi cekaman salinitas dengan dosis silika yang mempengaruhi luas daun 4 minggu setelah tanam. Dosis silika berpengaruh nyata terhadap bobot segar akar 4 minggu setelah tanam, biomassa 4 minggu setelah tanam, dan laju asimilasi bersih. Cekaman salinitas berpengaruh nyata terhadap biomassa 4 minggu setelah tanam. Peningkatan cekaman salinitas sampai $8 \mathrm{dS} \mathrm{m}^{-1}$ akan menurunkan luas daun dan biomasa tanaman sedangkan peningkatan cekaman salinitas sampai $12 \mathrm{dS} \mathrm{m}^{-1}$ dikombinasikan dengan dosis silika memperbaiki luas daun dan biomasa tanaman. Dosis optimum silika pada kondisi cekaman salinitas adalah 450 mg karena mampu meningkatkan biomasa dan laju asimilasi bersih. Sebaliknya peningkatan dosis silika sampai $600 \mathrm{mg}$ menyebabkan penurunan biomasa dan laju asimilasi bersih, tetapi dapat meningkatkan bobot segar akar.
\end{abstract}

Kata kunci: padi lokal, pertumbuhan, salinitas, silika

Abstract. Growth analysis in rice was important to imagine the growth and development of a plant that can be used to optimize production on sub-optimal conditions. This research aimed to determine the growth analysis of local rice accession PH1 under saline conditions with added solid silica fertilizer. The research used a Completely Randomized Design with two factors. The first factor was salinity stress with four levels include non-saline, $4 d S m-1,8 d S m-1$, and $12 d S$ $\mathrm{m}-1$. The second factor was silica dose per $\mathrm{kg}$ of soil with three levels include $300 \mathrm{mg}, 450 \mathrm{mg}$, and $600 \mathrm{mg}$. The results showed that there was an interaction between salinity stress and silica dose which affected the leaf area 4 weeks after planting. The dose of silica significantly affected root fresh weight 4 weeks after planting, biomass 4 weeks after planting, and net assimilation rate. Salinity stress significantly affected biomass 4 weeks after planting. Increasing the salinity stress to $8 \mathrm{dS} \mathrm{m-1}$ will decrease leaf area and plant biomass while increasing the salinity stress to $12 \mathrm{dS}$ m-1 combined with silica doses improves leaf area and plant biomass. The optimum dose of silica 
under salinity stress conditions is $450 \mathrm{mg}$ because it can increase biomass and net assimilation rate. Conversely, increasing the dose of silica to $600 \mathrm{mg}$ caused a decrease in biomass and net assimilation rate, but could increase root fresh weight.

Keywords: local rice, growth, salinity, silica

\section{Pendahuluan}

Pangan khususnya beras merupakan kebutuhan primer bagi mayoritas masyarakat di Indonesia. Kebutuhan terhadap beras meningkat setiap tahunnya seiring dengan peningkatan jumlah penduduk. Badan Pusat Statistik (2018) memproyeksikan pada tahun 2015-2020 laju pertumbuhan penduduk sebesar 1,07 \% dengan jumlah penduduk saat ini sebesar 269 juta jiwa, sehingga diperkirakan kebutuhan terhadap beras akan meningkat. Kebutuhan terhadap pangan beras Indonesia pada tahun 2019 sebesar 115,58 $\mathrm{kg} \mathrm{kapita}^{-1}$ tahun $^{-1}$ (Kementerian Pertanian, 2019). Disisi lain, produksi GKG di Indonesia pada tahun 2019 sebesar 54,60 juta ton (Badan Pusat Statistik, 2019) dan menjadi beras siap konsumsi sebesar 34,26 juta ton. Peningkatan jumlah penduduk harus dibarengi dengan peningkatan produksi beras akibat skema diversifikasi pangan di Indonesia belum dapat berjalan secara optimal. Oleh sebab itu, untuk menjamin kebutuhan pangan bagi masyarakat Indonesia dan agar dapat menyongsong ketahanan pangan maka perlu suatu usaha untuk meningkatkan produksi padi.

Salah satu upaya peningkatan produksi beras yaitu melalui perluasan areal tanam pada lahan sub-optimal seperti lahan salin. Hal tersebut karena Indonesia merupakan Negara kepulauan dengan garis pantai sepanjang $81.000 \mathrm{~km}$ (Dirhamsyah, 2006). Lahan-lahan sub optimal yang terletak di sekitar pantai dimugkinkan untuk diusahakan budidaya padi. Tentunya budidaya padi di lahan sub-optimal akan menemui sejumlah kendala seperti tingginya kadar garam pada tanah dan air, kecepatan angin, dan evapotranspirasi yang tinggi (Rachman et al., 2018). Kadar garam yang tinggi menyebabkan potensial osmotik pada sel menjadi tinggi sehingga menyebabkan gangguan fisiologis bagi tanaman (Aguilar et al., 2017). Berdasarkan penelitian Nasrudin and Kurniasih (2018) padi yang ditanam di lahan salin dapat menurunkan pertumbuhan jumlah anakan, luas daun, dan produksi biomasa. Hal tersebut akan sangat berpengaruh terhadap pengisian gabah (produktivitas) dan kualitas hasil.

Salah satu upaya yang dapat dilakukan agar padi yang ditanam ada lahan salin dapat tumbuh dan berkembang dengan baik yaitu melalui penambahan hara silika. Silika merupakan hara non esensial yang dibutuhkan tanaman padi untuk memperkuat dinding sel pada daun, akar, dan batang, meningkatkan fotosintesis, serta mengurangi keracunan garam dengan meningkatkan aktivitas enzim selama tercekam (Liang et al., 2007). Penambahan hara silika dengan konsentrasi 1-2 $\mathrm{mM}$ pada kondisi salin (daya hantar listrik $8 \mathrm{dS} \mathrm{m}^{-1}$ ) mampu mempertahankan hasil padi (Ikhsanti et al., 2018). Prawira et al., (2014) melaporkan dalam penelitiannya bahwa pemberian 
silika dengan dosis $400 \mathrm{mg} \mathrm{kg}^{-1}$ tanah dapat meningkatkan jumlah anakan, jumlah malai, presentase gabah isi, dan bobot gabah per rumpun. Silika yang diberikan dalam bentuk cair dengan dosis 1 L.ha $^{-1}$ juga mampu meningkatkan variabel fisiologi seperti biomasa tanaman (Tampoma et al., 2017).

Belum adanya penelitian yang membahas perlakuan salinitas dan silika pada padi lokal aksesi PH 1 menjadikan penelitian ini penting untuk dilakukan. Analisis pertumbuhan tanaman akan menggambarkan bagaimana proses fisiologis tanaman padi untuk menghasilkan asimilat untuk ditranslokasikan untuk pengisian gabah sehingga dapat meningkatkan produktivitas tanaman. Penggunaan varietas padi lokal jarang diupayakan oleh masyarakat karena produksinya yang rendah. Namun, varietas padi lokal umumnya memiliki ketahanan terhadap cekaman abiotik tertentu. Tujuan penelitian untuk mengetahui proses analisis pertumbuhan tanaman padi lokal aksesi PH 1 pada kondisi salin dengan penambahan pupuk silika padat.

\section{Bahan dan Metode}

\section{Alat dan Bahan}

Alat-alat yang digunakan antara lain: polybag ukuran 40 x $50 \mathrm{~cm}$, selang, gembor, meteran, bagan warna daun, oven Memmert type UN 260, timbangan digital $5 \mathrm{~kg}$, timbangan digital dengan akurasi 0,01 g, alat tulis, ember, gelas ukur, karton asturo, kamera, milimeter blok, amplop cokelat untuk sampel tanaman, plastik bening, double tape dan lakban, handsprayer, dan logbook. Bahanbahan yang dgunakan antara lain: benih padi lokal aksesi PH 1, pupuk NPK 16:16:16, hara silika padat $\mathrm{SiO}_{2}$, pupuk kandang, tanah, herbisida decis, pestisida, bakterisida, dan garam $\mathrm{NaCl}$.

\section{Rancangan Percobaan}

Penelitian menggunakan Rancangan Acak Lengkap faktorial. Faktor pertama yaitu tingkat cekaman salinitas yang terdiri atas empat taraf yaitu $\mathrm{S}_{0}$ (non salin), $\mathrm{S}_{1}\left(4 \mathrm{dS} \mathrm{m} \mathrm{m}^{-1}\right), \mathrm{S}_{2}\left(8 \mathrm{dS} \cdot \mathrm{m}^{-1}\right)$, dan $\mathrm{S}_{3}\left(12 \mathrm{dS} \mathrm{m}^{-1}\right)$. Faktor kedua yaitu penambahan dosis silika padat $\left(\mathrm{SiO}_{2}\right)$ per $\mathrm{kg}$ tanah yang terditi atas tiga taraf yaitu $\mathrm{A}_{1}(300 \mathrm{mg}), \mathrm{A}_{2}(450 \mathrm{mg})$, dan $\mathrm{A}_{3}(600 \mathrm{mg})$. Percobaan terdiri atas 12 kombinasi perlakuan dan diulang sebanyak tiga kali.

\section{Pelaksanaan Percobaan}

Penelitian menggunakan padi lokasl aksesi PH 1 asal Cisayong, Tasikmalaya. Benih padi disemai selama 14 hari kemudian dilakukan pindah tanam pada media tanam yang telah disiapkan dan disusun dalam rumah pelastik. Media tanam menggunakan tanah ultisol dan pupuk kandang sapi dengan perbandingan 1:1. Tanaman yang telah dipindahkan pada media tanam kemudian dipelihara meliputi pengendalian organisme pengganggu tanaman (OPT), pemupukan menggunakan pupuk NPK 16:16:16 dengan dosis $200 \mathrm{~kg} \mathrm{ha}^{-1}$, dan penyiraman. Pemberian pupuk NPK dilakukan bersamaan dengan pemberian pupuk silika padat yaitu saat tanaman berumur 10 
dan 50 hari setelah tanam (HST). Perlakuan salinitas diberikan saat tanaman berumur 14, 28, dan 56 hari setelah tanam (HST) sedangkan penambahan pupuk silika $\left(\mathrm{SiO}_{2}\right)$ diberikan berselang 3 hari setelah pemberian perlakuan salinitas.

\section{Parameter Pengamatan dan Analisis Data}

Parameter yang diamati antara lain: luas daun $\left(\mathrm{cm}^{2}\right)$, bobot basah tajuk $(\mathrm{g})$, bobot basah akar (g), kadar air tanaman (\%), dan biomasa tanaman (g) dilakukan secara destruktif. Luas daun diukur dengan cara menggambar daun padi yang diamati pada kertas milimeter blok kemudian dihitung luasannya pada daun yang tergambar. Bobot basah akar dan tajuk dilakukan dengan cara mencabut tanaman secara destruktif kemudian ditimbang menggunakan timbangan digital dan hasilnya dicatat pada lembar kerja. Biomassa tanaman dilakukan dengan cara tajuk dan akar segar dikeringkan menggunakan oven Memmert type UN 260 pada suhu $80^{\circ} \mathrm{C}$ selama 24 jam. Hasil pengeringan kemudian ditimbang menggunakan timbangan digital. Selisih penimbangan biomassa dengan bobot segar yang dikalikan 100\% dijadikan sebagai kadar air tanaman. Indeks luas daun dilakukan dengan cara mengukur luasan daun padi per tanaman dengan jarak tanam tertentu. Menurut Gardner et al., (1991), data yang diperoleh dihitung menggunakan persamaan (1)

ILD $=\frac{1}{\text { luas lahan }} \times$ luas daun

Nisbah luas daun dilakukan dengan cara mengukur luasan daun padi per tanaman dan biomassa tanaman. Menurut Gardner et al., (1991), data yang diperoleh dihitung menggunakan persamaan persamaan (2)

$\mathrm{NLD}=\frac{\left(\frac{\text { Luas daun pada } 8 M S T}{\text { Biomasa pada } 8 M S T}\right)+\left(\frac{\text { Luas daun pada } 4 M S T}{\text { Biomasa pada } 4 M S T}\right)}{2}$

Laju asimilasi bersih $\left(\mathrm{g} \mathrm{cm}^{-2}\right.$ minggu $\left.{ }^{-1}\right)$ merupakan kemampuan tanaman dalam menghasilkan bahan kering hasil asimilasi per satuan luas daun per satuan waktu. Pengamatan laju asimilasi bersih dilakukan dengan cara mengukur luasan daun padi per tanaman dan biomassa per tanaman. Menurut Gardner et al., (1991), data yang diperoleh dihitung menggunakan persamaan (3)

$\operatorname{LAB}\left(\mathrm{g} \mathrm{dm}^{-2} \operatorname{minggu}^{-1}\right)=\frac{W 2-W 1}{T 2-T 1} \times \frac{\ln L a 2-\ln L a 1}{L a 2-L a 1}$

Keterangan: $\mathrm{W}_{2}$ (biomasa pada 8 minggu setelah tanam); $\mathrm{W}_{1}$ (biomasa pada 4 minggu setelah tanam); $\mathrm{T}_{2}$ (waktu pengamatan saat 8 minggu setelah tanam); $\mathrm{T}_{1}$ (waktu pengamatan saat 4 minggu setelah tanam); La2 (luas daun saat 8 minggu setelah tanam); La 1 (luas daun saat 4 minggu setelah tanam).

Data kuantitatif yang diperoleh kemudian dianalisis menggunakan analisis ragam (ANOVA). Apabila terdapat perbedaan diantara perlakuan, maka dilanjutkan dengan Uji DMRT (Duncan's multiple range test) pada taraf kesalahan 5\%. Analisis korelasi dilakukan untuk mengetahui hubungan antar parameter yang diamati menggunakan Pearson correlation. Analisis data statistika menggunakan software Statistical Tool for Agricultural Research (STAR) ver 2.0.1. 


\section{Hasil dan Pembahasan}

Analisis pertumbuhan tanaman merupakan variabel yang sangat menentukan produktivitas suatu tanaman termasuk tanaman padi. Kajian fisiologi tumbuhan menggambarkan bagaimana lingkungan dapat mempengaruhi sistem metabolisme tanaman sehingga terdapat tanggapan dari tanaman. Salah satu organ tanaman yang dapat menggambarkan kaitannya dengan fisiologi tanaman yaitu daun. Berbagai proses metabolisme diantaranya fotosintesis, respirasi, dan transpirasi dapat berlangsung pada daun. Proses metabolisme tersebut sangat mempengaruhi produksi biomasa dan produktivitas tanaman.

Tabel 1. Tingkat cekaman salinitas dan penambahan dosis silika pada luas daun umur 4 MST padi lokal aksesi PH 1.

\begin{tabular}{|c|c|c|c|c|}
\hline \multicolumn{5}{|c|}{ Luas daun $\left(\mathrm{cm}^{2}\right) 4 \mathrm{MST}$} \\
\hline \multirow{2}{*}{ Perlakuan } & \multicolumn{3}{|c|}{ Dosis silika (per kg tanah) } & \multirow{2}{*}{ Rerata } \\
\hline & $\mathrm{A}_{1}(300 \mathrm{mg})$ & $\mathrm{A}_{2}(450 \mathrm{mg})$ & $\mathrm{A}_{3}(600 \mathrm{mg})$ & \\
\hline \multicolumn{5}{|l|}{ Salinitas } \\
\hline $\mathrm{S}_{0}$ (non salin) & $63,53^{\mathrm{cd}}$ & $74,6^{\mathrm{cd}}$ & $121,00^{\mathrm{b}}$ & 86,38 \\
\hline $\mathrm{S}_{1}\left(4 \mathrm{dS} \mathrm{m}^{-1}\right)$ & $185,98^{\mathrm{a}}$ & $66,90^{\mathrm{cd}}$ & $108,11^{b}$ & 120,33 \\
\hline $\mathrm{S}_{2}\left(8 \mathrm{dS} \mathrm{m}^{-1}\right)$ & $52,70^{\mathrm{d}}$ & $68,66^{\mathrm{cd}}$ & $83,14^{\mathrm{c}}$ & 68,17 \\
\hline $\mathrm{S}_{3}\left(12 \mathrm{dS} \mathrm{m}^{-1}\right)$ & $58,51^{\mathrm{d}}$ & $173,73^{\mathrm{a}}$ & $60,58^{\mathrm{d}}$ & 97,61 \\
\hline Rerata & 90,18 & 95,97 & 93,21 & $93,12(+)$ \\
\hline CV (\%) & & $35,57^{*}$ & & \\
\hline
\end{tabular}

Keterangan: (+) ada interaksi; mst (minggu setelah tanam); $\left({ }^{*}\right) \mathrm{CV}$ dengan data ditransformasi; angka yang diikuti oleh huruf yang berbeda, berbeda nyata pada Uji DMRT 5\%.

Saat padi berumur 4 minggu setelah tanam (MST), terjadi interaksi antara cekaman salinitas dengan penambahan dosis silika. Tabel 1 menggambarkan pada kondisi salinitas rendah, penambahan silika sebanyak $600 \mathrm{mg} \mathrm{kg}^{-1}$ tanah sangat membantu peningkatan luas daun. Namun, saat tanaman tercekam salinitas sampai 8 - $12 \mathrm{dS} \mathrm{m}^{-1}$ penambahan dosis silika cukup dengan dosis $450 \mathrm{mg}$. Hal tersebut diduga peningkatan luasan daun pada kondisi silika tinggi karena langsung dapat mempengaruhi sel dan jaringan tanaman. Sebagaimana diketahui bahwa silika memiliki fungsi pada tanaman yaitu menurunkan transpirasi pada saat tanaman kekurangan air, meningkatkan toleransi tanaman terhadap cekaman biotik dan abiotik, dan memperkuat dinding sel (Ansari et al., 2016). Kondisi cekaman salinitas rendah memudahkan silika terakumulasi di dalam sel termasuk sel daun. Dehaghi et al. (2018) menyebutkan bahwa silika terdeposit di dalam dinding sel daun, batang, dan sel epidermis. Hal tersebut akan memperkuat dinding sel pada daun dan batang sehingga saat kondisi tanaman tercekam masih dapat melangsungkan proses metabolisme secara optimal.

Tabel 2 menunjukkan bahwa luas daun pada 8 MST, indeks luas daun, dan nisbah luas daun tidak berpengaruh nyata terhadap cekaman salinitas dan penambahan dosis silika. Meskipun tidak berbeda nyata, ketiga parameter tersebut menunjukkan bahwa semakin tinggi cekaman 
salinitas maka akan menurunkan luasan daun. Hal tersebut diduga kandungan garam yang diserap oleh tanaman mempengaruhi proses fotosintesis dan penyerapan unsur hara. Tanaman akan terganggu dalam proses penyerapan unsur hara akibat tekanan osmotik di luar sel lebih rendah, sehingga garam dengan valensi rendah lebih mudah masuk dibandingkan unsur hara lain yang dibutuhkan tanaman (Munns \& Tester, 2008). Konsentrasi ion $\mathrm{Na}^{+}$yang tinggi menyebabkan terganggunya proses fotosintesis (Gupta \& Huang, 2014) sehingga akan menurunkan kemampuan tanaman dalam menangkap cahaya, degradasi klorofil, dan luasan daun (Ghosh et al., 2016).

Tabel 2. Luas daun umur 8 MST, indeks luas daun umur 4 dan 8 MST, serta nisbah luas daun padi lokal aksesi PH 1 dengan penambahan dosis pupuk silika pada kondisi salin.

\begin{tabular}{|c|c|c|c|c|}
\hline \multirow{2}{*}{ Perlakuan } & \multirow{2}{*}{$\begin{array}{c}\text { Luas daun }\left(\mathrm{cm}^{2}\right) \\
8 \mathrm{MST}\end{array}$} & \multicolumn{2}{|c|}{ Indeks luas daun } & \multirow{2}{*}{ Nisbah luas daur } \\
\hline & & 4 MST & 8 MST & \\
\hline \multicolumn{5}{|l|}{ Salinitas } \\
\hline $\mathrm{S}_{0}$ (non salin) & $1143,52^{\mathrm{a}}$ & $0,22^{\mathrm{a}}$ & $2,86^{\mathrm{a}}$ & $595,51^{\mathrm{a}}$ \\
\hline $\mathrm{S}_{1}\left(4 \mathrm{dS} \mathrm{m}^{-1}\right)$ & $1130,13^{\mathrm{a}}$ & $0,30^{\mathrm{a}}$ & $2,83^{\mathrm{a}}$ & $328,80^{\mathrm{a}}$ \\
\hline $\mathrm{S}_{2}\left(8 \mathrm{dS} \mathrm{m}^{-1}\right)$ & $849,12^{\mathrm{a}}$ & $0,17^{\mathrm{a}}$ & $2,12^{\mathrm{a}}$ & $484,12^{\mathrm{a}}$ \\
\hline $\mathrm{S}_{3}\left(12 \mathrm{dS} \mathrm{m}^{-1}\right)$ & $977,99^{\mathrm{a}}$ & $0,18^{\mathrm{a}}$ & $2,44^{\mathrm{a}}$ & $268,48^{\mathrm{a}}$ \\
\hline \multicolumn{5}{|c|}{ Dosis silika (per kg tanah) } \\
\hline A1 $(300 \mathrm{mg})$ & $1149,07^{p}$ & $0,23^{\mathrm{p}}$ & $2,87^{p}$ & $372,76^{p}$ \\
\hline A2 (450 mg) & $1010,80^{p}$ & $0,19^{p}$ & $2,53^{p}$ & $500,51^{p}$ \\
\hline $\mathrm{A} 2(600 \mathrm{mg})$ & $915,70^{p}$ & $0,23^{p}$ & $2,29^{p}$ & $384,41^{\mathrm{p}}$ \\
\hline Interaksi & - & - & - & - \\
\hline CV (\%) & $23,22^{*}$ & $9,21^{*}$ & $18,73^{*}$ & $33,55^{*}$ \\
\hline
\end{tabular}

Keterangan: (-) tidak ada interaksi; mst (minggu setelah tanam); (*) CV dengan data ditransformasi; angka yang diikuti oleh huruf yang sama pada kolom yang sama, tidak beda nyata pada Uji DMRT 5\%.

Tabel 3. Korelasi antar parameter pengamatan menggunakan Pearson correlation

\begin{tabular}{|c|c|c|c|c|c|c|c|c|c|c|c|}
\hline & $\mathbf{A}_{1}$ & $\mathbf{A}_{2}$ & $\mathbf{B}_{1}$ & $\mathbf{B}_{2}$ & $\mathbf{C}_{1}$ & $\mathrm{C}_{2}$ & $\mathbf{D}_{1}$ & $\mathbf{D}_{2}$ & $\mathbf{E}_{1}$ & $\mathbf{E}_{2}$ & $\mathbf{F}$ \\
\hline$\overline{A_{1}}$ & $1^{* *}$ & & & & & & & & & & \\
\hline $\mathbf{A}_{2}$ & $0,19^{\text {tn }}$ & $1^{* *}$ & & & & & & & & & \\
\hline $\mathbf{B}_{1}$ & $1^{* *}$ & $0,19^{\mathrm{tn}}$ & $1^{* *}$ & & & & & & & & \\
\hline $\mathbf{B}_{2}$ & $0,19^{\text {tn }}$ & $1^{* *}$ & $0,19^{\text {tn }}$ & $1^{* *}$ & & & & & & & \\
\hline$C_{1}$ & $0,51^{* *}$ & $-0,11^{\text {tn }}$ & $0,51^{* *}$ & $-0,11^{\mathrm{tn}}$ & $1^{* *}$ & & & & & & \\
\hline $\mathrm{C}_{2}$ & $0,07^{\text {tn }}$ & $0,06^{\mathrm{tn}}$ & $0,07 \mathrm{tn}$ & $0,06^{\mathrm{tn}}$ & $-0,06^{\mathrm{tn}}$ & $1^{* *}$ & & & & & \\
\hline $\mathbf{D}_{1}$ & $0,53^{* *}$ & $0,05^{\text {tn }}$ & $0,53^{* *}$ & $0,05^{\text {tn }}$ & $0,62^{* *}$ & $-0,12^{\text {tn }}$ & $1^{* *}$ & & & & \\
\hline $\mathbf{D}_{2}$ & $-0,07^{\text {tn }}$ & $0,16^{\mathrm{tn}}$ & $-0,07^{\text {tn }}$ & $0,16^{\mathrm{tn}}$ & $-0,07^{\text {tn }}$ & $0,64^{* *}$ & $-0,01^{\mathrm{tn}}$ & $1^{* *}$ & & & \\
\hline $\mathbf{E}_{1}$ & $0,70^{* *}$ & $0,01^{\mathrm{tn}}$ & $0,70^{* *}$ & $0,01^{\mathrm{tn}}$ & $0,66^{* *}$ & $-0,08^{\text {tn }}$ & $0,76^{* *}$ & $-0,06^{\text {tn }}$ & $1^{* *}$ & & \\
\hline $\mathbf{E}_{2}$ & $0,09^{\text {tn }}$ & $0,63^{* *}$ & $0,09_{\mathrm{tn}}$ & $0,63^{* *}$ & $-0,04^{\text {tn }}$ & $0,28^{*}$ & $-0,07^{\mathrm{tn}}$ & $0,39^{*}$ & $-0,12^{\operatorname{tn}}$ & $1^{* *}$ & \\
\hline $\mathbf{F}$ & $-0,34^{*}$ & $0,31^{*}$ & $-0,34^{*}$ & $0,31^{*}$ & $-0,22^{\text {tn }}$ & $0,25^{*}$ & $-0,24^{\mathrm{tn}}$ & $0,30^{*}$ & $-0,35^{*}$ & $0,77^{* *}$ & $1^{* *}$ \\
\hline
\end{tabular}

Keterangan: * (berkorelasi nyata); ${ }^{* *}$ (berkorelasi sangat nyata); ${ }^{\text {tn }}$ (tidak berkorelasi); A (luas daun saat tanaman berumur 4 MST); $\mathrm{A}_{2}$ (luas daun saat tanaman berumur 8 MST); $\mathrm{B}_{1}$ (indeks luas daun saat tanaman berumur $4 \mathrm{MST}$ ); $\mathrm{B}_{2}$ (indeks luas daun saat tanaman berumur $8 \mathrm{MST}$ ); $\mathrm{C}_{1}$ (bobot segar akar saat tanaman berumur $4 \mathrm{MST}$ ); $\mathrm{C}_{2}$ (bobot segar akar saat tanaman berumur $8 \mathrm{MST}$ ); $\mathrm{D}_{1}$ (bobot segar tajuk saat tanaman berumur 4 MST); $\mathrm{D}_{2}$ (bobot segar tajuk saat tanaman berumur $8 \mathrm{MST}$ ); $\mathrm{E}_{1}$ (biomasa tanaman saat tanaman berumur $4 \mathrm{MST}$ ); $\mathrm{E}_{2}$ (biomasa tanaman saat tanaman berumur $8 \mathrm{MST}$ ); F (laju asimilasi bersih). 
Tabel 4. Bobot segar tajuk umur 4 dan 8 MST, bobot segar akar umur 4 dan 8 MST, serta kadar air tanaman umur 4 dan 8 MST padi lokal aksesi PH 1 dengan penambahan dosis pupuk silika pada kondisi salin.

\begin{tabular}{|c|c|c|c|c|c|c|}
\hline \multirow[t]{2}{*}{ Perlakuan } & \multicolumn{2}{|c|}{ BST (g) } & \multicolumn{2}{|c|}{ BSA (g) } & \multicolumn{2}{|c|}{ Kadar air (\%) } \\
\hline & 4 MST & 8 MST & 4 MST & 8 MST & 4 MST & 8 MST \\
\hline Salinitas & & & & & & \\
\hline $\mathrm{S}_{0}$ (non salin) & $1,49^{\mathrm{a}}$ & $42,76^{\mathrm{a}}$ & $0,21^{\mathrm{a}}$ & $5,98^{\mathrm{a}}$ & $85,14^{\mathrm{a}}$ & $73,90^{\mathrm{a}}$ \\
\hline $\mathrm{S}_{1}\left(4 \mathrm{dS} \mathrm{m}^{-1}\right)$ & $1,97^{\mathrm{a}}$ & $42,09^{\mathrm{a}}$ & $0,36^{\mathrm{a}}$ & $4,86^{\mathrm{a}}$ & $77,39^{\mathrm{a}}$ & $67,82^{\mathrm{a}}$ \\
\hline $\mathrm{S}_{2}\left(8 \mathrm{dS} \mathrm{m}^{-1}\right)$ & $2,10^{\mathrm{a}}$ & $53,12^{\mathrm{a}}$ & $0,29^{\mathrm{a}}$ & $5,55^{\mathrm{a}}$ & $85,18^{\mathrm{a}}$ & $84,65^{\mathrm{a}}$ \\
\hline $\mathrm{S}_{3}\left(12 \mathrm{dS} \mathrm{m}^{-1}\right)$ & $1,89^{\mathrm{a}}$ & $60,22^{\mathrm{a}}$ & $0,34^{\mathrm{a}}$ & $7,32^{\mathrm{a}}$ & $85,55^{\mathrm{a}}$ & $78,50^{\mathrm{a}}$ \\
\hline Dosis silika (per kg & & & & & & \\
\hline A1 $(300 \mathrm{mg})$ & $2,04^{\mathrm{p}}$ & $56,55^{\mathrm{p}}$ & $0,29^{p q}$ & $6,96^{p}$ & $85,45^{p}$ & $74,83^{\mathrm{p}}$ \\
\hline A2 $(450 \mathrm{mg})$ & $0,97^{p}$ & $46,68^{p}$ & $0,19^{q}$ & $5,87^{p}$ & $79,24^{p}$ & $70,84^{\mathrm{p}}$ \\
\hline A2 $(600 \mathrm{mg})$ & $2,58^{p}$ & $45,63^{p}$ & $0,43^{p}$ & $4,95^{\mathrm{p}}$ & $85,25^{\mathrm{p}}$ & $82,9^{p}$ \\
\hline Interaksi & - & - & - & - & - & - \\
\hline CV (\%) & $39,42^{*}$ & $23,49^{*}$ & $12,97^{*}$ & 33,02 & 9,76 & 19,97 \\
\hline
\end{tabular}

Keterangan: (-) tidak ada interaksi; mst (minggu setelah tanam); (*) CV dengan data ditransformasi; BST (bobot segar tajuk); BSA (bobot segar akar); angka yang diikuti oleh huruf yang sama pada kolom yang sama, tidak beda nyata pada Uji DMRT 5\%.

Tabel 4 menunjukkan bahwa bobot segar tajuk, bobot segar akar, dan kadar air tidak berbeda nyata antar perlakuan cekaman salinitas. Bobot segar akar saat tanaman berumur 4 MST berbeda nyata antar perlakuan dosis silika. Semakin tinggi dosis silika sampai $600 \mathrm{mg} \mathrm{kg}^{-1}$ tanah maka pertumbuhan akar padi lebih tinggi. Silika akan masuk ke dalam tanaman melalui akar untuk kemudian terdeposit pada sel daun. Berdasarkan analisis korelasi (Tabel 3), pertumbuhan daun berkorelasi positif terhadap bobot segar akar $(\mathrm{R}=0,51)$ artinya daun yang luas akibat bantuan silika yang membantu dalam toleransi terhadap salinitas mengakumulasi asimilat hasil fotosintesis. Asimilat yang dihasilkan sebagian digunakan tanaman untuk membantu pertumbuhan akar. Radanielson et al. (2017) menyebutkan bahwa pertumbuhan akar yang lebih baik akibat usaha tanaman dalam menjangkau nutrisi. Salah satu nutrisi yang dijangkau dan diserap oleh akar yaitu silika yang terdeposit pada sel daun, batang, dan sel epidermis. Hal tersebut akibat potensial osmotik di luar sel lebih rendah sehingga akar harus memiliki usaha yang lebih kuat dalam menggapai dan menyerap hara mineral termasuk air.

Biomasa merupakan hasil serapan $\mathrm{CO}_{2}$ oleh tanaman kemudian diproses melalui fotosintesis. Produksi biomasa pada tanaman sangat penting karena akan menentukan kuantitas dan kualitas hasil padi. Tabel 5 menunjukkan bahwa biomasa padi yang ditanam pada tingkat cekaman salinitas berbeda nyata yaitu semakin tinggi tingkat salinitas maka biomasanya semakin rendah. Peningkatan cekaman salinitas akan menurunkan biomasa akibat keterbatasan tanaman dalam melakukan penyerapan hara yang dibutuhkan tanaman. Berdasarkan penelitian Haq et al. (2009) semakin tinggi tingkat salinitas akan menurunkan bobot segar tajuk dan biomasa. Cekaman salinitas yang rendah menyebabkan pertumbuhan daun lebih luas sehingga laju fotosintesis 
menjadi lebih tinggi. Berdasarkan analisis korelasi (Tabel 3), biomasa tanaman berkorelasi positif terhadap luas daun $(R=0,52)$ dan bobot segar tajuk $(R=0,64)$. Apabila tanaman memiliki daun yang luas maka penyerapan sinar matahari akan lebih cepat sehngga hasil fotosintesis akan lebih banyak yang dapat digunakan sebagai energi untuk pertambahan sel serta biomasaa tanaman.

Tabel 5. Biomasa padi umur 4 dan 8 MST serta laju asimilasi bersih padi lokal aksesi PH 1 dengan penambahan dosis pupuk silika pada kondisi salin.

\begin{tabular}{|c|c|c|c|}
\hline \multirow[t]{2}{*}{ Perlakuan } & \multicolumn{2}{|c|}{ Biomasa $(g)$} & \multirow{2}{*}{$\begin{array}{l}\text { Laju asimilasi bersih } \\
\left(\mathrm{g} \mathrm{dm}^{-2} \mathrm{minggu}^{-1}\right)\end{array}$} \\
\hline & 4 MST & 8 MST & \\
\hline Salinitas & & & \\
\hline $\mathrm{S}_{0}$ (non salin) & $0,18^{\mathrm{a}}$ & $16,02^{\mathrm{a}}$ & $0,89^{a}$ \\
\hline $\mathrm{S}_{1}\left(4 \mathrm{dS} \mathrm{m}^{-1}\right)$ & $0,42^{\mathrm{a}}$ & $18,71^{\mathrm{a}}$ & $0,99^{\mathrm{a}}$ \\
\hline $\mathrm{S}_{2}\left(8 \mathrm{dS} \mathrm{m}^{-1}\right)$ & $0,30^{\mathrm{a}}$ & $9,78^{\mathrm{b}}$ & $0,72^{\mathrm{a}}$ \\
\hline $\mathrm{S}_{3}\left(12 \mathrm{dS} \mathrm{m}^{-1}\right)$ & $0,36^{\mathrm{a}}$ & $18,47^{\mathrm{a}}$ & $1,10^{\mathrm{a}}$ \\
\hline \multicolumn{4}{|c|}{ Dosis silika (per kg tanah) } \\
\hline A1 $(300 \mathrm{mg})$ & $0,31^{p}$ & $18,37^{p}$ & $1,07^{p}$ \\
\hline A2 (450 mg) & $0,23^{p}$ & $17,19^{p}$ & $1,12^{p}$ \\
\hline A2 (600 mg) & $0,39^{p}$ & $11,66^{\mathrm{q}}$ & $0,60^{q}$ \\
\hline Interaksi & - & - & - \\
\hline CV (\%) & 20,01* & $\mathbf{3 7 , 5 2}$ & $20,45^{*}$ \\
\hline
\end{tabular}

Keterangan: (-) tidak ada interaksi; mst (minggu setelah tanam); (*) CV dengan data ditransformasi; angka yang diikuti oleh huruf yang sama pada kolom yang sama, tidak beda nyata pada Uji DMRT 5\%.

Penambahan silika juga berpengaruh nyata terhadap produksi biomasa dan laju asimilasi bersih. Tabel 5 menunjukkan bahwa semakin tinggi dosis silika akan menurunkan biomasa dan laju asimilasi bersih padi. Diduga semakin tinggi dosis silika yang diberikan pada tanaman maka penyerapannya akan terhambat. Hal tersebut akibat terjadinya kompetisi penyerapan hara yaitu hara yang bervalensi rendah akan lebih mudah diserap oleh akar tanaman. Ion $\mathrm{Na}^{+}$akan lebih mudah diserap oleh akar karena memiliki valensi lebih rendah dibandingkan Si. Oleh sebab itu, peningkatan dosis Si kurang dapat mempengaruhi terhadap produksi biomasa dan laju asimilasi bersih. Berdasarkan analisis korelasi (Tabel 3), biomasa tanaman berkorelasi positif terhadap laju asimilasi bersih $(\mathrm{R}=0,77)$. Hal ini menunjukkan bahwa asimilat yang dihasilkan oleh tanaman melalui fotosintesis disimpan pada organ seperti tajuk dan akar.

Proses fisiologi akan menentukan produksi biomasa dan produktivitas dari tanaman padi. Cekaman lingkungan seperti salinitas akan mengambat proses fisiologi tumbuhan seperti menurunkan luasan daun, penyerapan hara mineral, laju fotosintesis, dan degradasi klorofil. Gangguan tersebut menyebabkan tanaman kesulitan dalam memproduksi biomasa. Oleh sebab itu, penambahan silika pada kondisi salin dengan dosis sampai $450 \mathrm{mg} \mathrm{kg}^{-1}$ tanah diduga mampu memperbaiki proses fisiologi padi dan mempengaruhi produksi biomasa. Produksi biomasa yang tinggi akan berdampak pada kuantitas dan kualitas hasil padi. 


\section{Kesimpulan}

Cekaman salinitas mempengaruhi analisis pertumbuhan tanaman padi lokal aksesi PH 1 yang ditunjukkan dengan menurunnya luas daun dan biomasa tanaman pada pemberian salinitas. Namun peningkatan cekaman salinitas sampai $12 \mathrm{dS} \mathrm{m}^{-1}$ yang dikombinasikan dengan penambahan $450 \mathrm{mg} \mathrm{kg}^{-1}$ tanah dosis silika padat mampu memperbaiki luas daun dan biomasa tanaman. Dosis silika optimum pada kondisi cekaman salinitas adalah $450 \mathrm{mg} \mathrm{kg}^{-1} \mathrm{karena} \mathrm{mampu}$ meningkatkan biomasa dan laju asimilasi bersih. Sebaliknya, penambahan pupuk silika dengan dosis $600 \mathrm{mg} \mathrm{kg}{ }^{-1}$ dapat menurunkan biomasa dan laju asimilasi bersih, namun dapat meningkatkan bobot segar tanaman.

\section{Ucapan Terima Kasih}

Penulis mengucapkan terima kasih kepada Kementerian Riset dan Teknologi / Badan Riset dan Inovasi Nasional yang telah mendanai penelitian ini dengan nomor kontrak 080/SP2H/AMD/LT/DPRM/2020; 011/SP2H/AMD/LT-MONO/LL4/2020; 217/KP/LP2MUP/09/2020. Penulis juga mengucapkan terima kasih kepada Ibu Siti Nurhidayah, M.Si. yang telah mensuplai kebutuhan benih padi aksesi PH 1 untuk penelitian ini.

\section{Daftar Pustaka}

Aguilar, M., Fernández-ramírez, J. L., Aguilar-blanes, M., \& Ortiz-romero, C. (2017). Rice sensitivity to saline irrigation in Southern Spain. Agricultural Water Management, 188(2017), 21-28. https://doi.org/10.1016/j.agwat.2017.03.027

Ansari, T. H., Iwasaki, K., Yoshida, T., Yamamoto, Y., \& Miyazaki, A. (2016). Status of nutrient elements in rice grain in relation to silicon accumulation pattern during grain filling. Bangladesh Agronomy Journal 19(2), 125-137.

Badan Pusat Statistik. (2018, Desember 2020). Proyeksi penduduk Indonesia 2015-2045. Retrieved from https://www.bps.go.id/

Badan Pusat Statistik. (2019, May 03). Luas panen, produksi, dan produktivitas padi menurut provinsi. Retrieved from https://www.bps.go.id/dynamictable/2019/04/15/1608/luas-panenproduksi-dan-produktivitas-padi-menurut-provinsi-2018.html

Dehaghi, M. A., Agahi, K., \& Kiani, S. (2018). Agromorphological response of rice (Oryza sativa L .) to foliar application of potassium silicate. Biharban Biologist 12(1), 33-36.

Dirhamsyah. (2006). Pengelolaan wilayah pesisir terintegrasi di Indonesia. Jurnal Oseana 31(1), 21-26.

Gardner, F. P., Pearce, R. B., dan Mitchell, R. L. (1991). Fisiologi Tanaman Budidaya. Jakarta, Indonesia: UI Press.

Ghosh, B., Ali, N., \& Gantait, S. (2016). Response of rice under salinity stress : a review update. Journal of Research Rice 4(2), 2-9. https://dx.doi.org/10.4172/2375-4338.1000167

Gupta, B., \& Huang, B. (2014). Mechanism of salinity tolerance in plants: physiological, biochemical, and molecular characterization. International Journal of Genomics (2014), 118. https://dx.doi.org/10.1155/2014/701596

Haq, T. U., Akhtar, J., Nawaz, S., \& Ahmad, R. (2009). Morpho-physiological response of rice (Oryza sativa L.) varieties to salinity stress. Pakistan Journal of Botany 41(6), 2943-2956.

Ikhsanti, A., Kurniasih, B., \& Indradewa, D. (2018). Pengaruh aplikasi silika terhadap pertumbuhan dan hasil tanaman padi (Oryza sativa L.) pada kondisi salin. Jurnal vegetalika 
7(4), 1-11.

Kementerian Pertanian. (2019). Stok Beras Aman Sampai 2020. Retrieved April 17, 2020, from https://www.pertanian.go.id/home/?show=news\&act=view\&id=4108

Liang, Y., Sun, W., Zhu, Y., \& Christie, P. (2007). Mechanisms of silicon-mediated alleviation of abiotic stresses in higher plants : A review. Environmental pollution 147 (2007), 422-428. https://doi.org/10.1016/j.envpol.2006.06.008

Munns, R., \& Tester, M. (2008). Mechanisms of salinity tolerance. Annual Review of Plant Biology, 59(1), 651-681. https://doi.org/10.1146/annurev.arplant.59.032607.092911

Nasrudin, N \& Kurniasih, B. (2018). Growth and yield of Inpari 29 rice varieties on raised-bed and different depths of sunken-bed in saline field. Jurnal Ilmu Pertanian (Agricultural Science) 3(3), 135-145. https://doi.org/10.22146/ipas.38736

Prawira, R. A., Agustiansyah, Ginting, Y., \& Nurmiaty, Y. (2014). Pengaruh aplikasi silika dan boron terhadap pertumbuhan dan produksi tanaman padi (Oryza sativa L.). Jurnal Agrotek Tropika 2(2), 282-288.

Rachman, A., Dariah, A., \& Sutono, S. (2018). Pengelolaan sawah salin berkadar garam tinggi. Jakarta, Indonesia: IIAARD Press.

Radanielson, A. M., Angeles, O., Li, T., Ismail, A. M., \& Gaydon, D. S. (2017). Describing the physiological responses of different rice genotypes to salt stress using sigmoid and piecewise linear functions. Field Crops Research, (2017), 1-11. https://doi.org/10.1016/j.fcr.2017.05.001

Tampoma, W. P., Nurmala, T., \& Rachmadi, M. (2017). Pengaruh dosis silika terhadap karakter fisiologi dan hasil tanaman padi (Oryza sativa L .) kultivar lokal poso ( kultıvar 36-Super dan Tagolu ). Jurnal Kultivasi 16(2), 320-325 